\title{
Non-Discrimination, Minority Rights and Self-Determination: Turkey's Post-Coup State of Emergency and the Position of Turkey's Kurds
}

\author{
Emre Turkut and Thomas Phillips \\ Emre Turkut (*) \\ Ghent Rolin-Jaequemyns International Law Institute (GRILI), Ghent University. \\ e-mail: Emre.Turkut@,UGent.be \\ Thomas Phillips \\ Liverpool John Moores University \\ e-mail: T.J.Phillips@ljmu.ac.uk
}

\begin{abstract}
States of emergency are often declared due to underlying problems of minority group accommodation, and the extraordinary limitation of rights arising from them tends to have a particularly striking effect on such groups. This was true, for instance, with the emergency measures adopted by the British authorities in the context of the 'Troubles' in Northern Ireland. The same appears true in respect of the Turkish state of emergency in the aftermath of the failed military coup of 15 July 2016 vis-à-vis the position of Turkey's Kurds. In spite of the fact that the declaration of the state of emergency constituted a response to an attempted coup which was, allegedly, orchestrated by the Gülen Movement, it is clear that the resulting derogating measures have also targeted 'other individuals and organizations', mainly those allegedly connected to the PKK (Kurdistan Workers' Party), and thus extended to Turkey's Kurdish periphery. This chapter seeks to map the impact of the Turkish post-coup derogation measures on Turkey's Kurds and to test them against the non-discrimination principle, minority rights, and the right of self-determination.
\end{abstract}

Keywords: emergency, Kurds, non-discrimination, minority rights, self-determination, Turkey.

\subsection{Introduction}

The application of human rights during public emergencies is one of the main legal challenges of our times. Based on ample evidence of actual practice (i.e. France and the United Kingdom), emergency regimes - particularly when coupled with broad-reaching and vague anti-terrorism laws - tend to be accompanied by gross and systematic human rights abuses aswhen states arrogate extraordinary powers to address threats to public order (OSCE 2018). This trend is recently exemplified by the far-reaching derogation measures adopted by Turkish authorities after the failed military coup of 15 July 2016.

In the aftermath of the attempted coup, on 21 July 2016, Turkey declared a nationwide state of emergency and lodged a derogation notice with the Council of Europe (CoE) to derogate from the European Convention on Human Rights (ECHR) pursuant to Article 15 thereof, referring to the 15 July coup attempt and its aftermath together with the 'other' 
terrorist attacks. ${ }^{1}$ A similar notification was lodged with the UN Secretary-General on 2 August 2016 pursuant to Article 4 of the International Covenant on Civil and Political Rights (ICCPR). ${ }^{2}$ Since the initial declaration, the state of emergency was prolonged seven times for a total period of 24 months until it was eventually lifted on 17 July $2018 .^{3}$

A closer examination of the derogation measures undertaken by Turkey during the period of emergency rule suggests that the post-coup measures reached their apotheosis through mass detentions and institutional closures, and through the collective dismissals of public servants (Ruys and Turkut 2018). Turkey adopted a scattergun approach to human rights curtailment, which involved severe repression based, in many cases, on a very tenuous connection with the raison d'etre of the state of emergency (Turkut 2019). As a result, the emergency decrees targeted a wide range of human rights. Although the state of emergency was lifted in July 2018, many of the exceptional emergency powers have concretized into new, permanent anti-terrorism legislation, which has been described as 'normalizing the state of emergency' (EU Progress Report 2019), and have found institutional form in Turkey's new presidential system of government, which is incompatible with elementary constitutional principles such as the separation of powers (Human Rights Watch 2018).

States of emergency are often linked to the inadequate or non-existent protection of minority rights, and the extraordinary limitation of rights during these crises tends to have a striking impact on minorities both collectively and individually. This was true, for instance, with the emergency measures adopted by Britain, particularly the unequal use of detention and internment against the Catholic minority, in the context of the 'Troubles' in Northern Ireland (Bakircioglu and Dickson 2017). More recently, warrantless house raids and arrests of Muslims during France's state of emergency in the aftermath of the 2015 Paris attacks have raised similar 'community profiling' and 'discrimination' concerns (Human Rights Watch 2016 and Codaccioni 2018). The same also appears true in respect of the Turkish state of emergency and the parlous situation of its Kurdish population. Although the declaration of the state of emergency was an immediate response to the attempted coup, the derogating measures have not been targeted exclusively at the Gülen Movement, a group designated as the Fetullahist Terrorist Organization/the Parallel State Structure (FETÖ/PDY) (which, it is claimed, was responsible for the failed coup), but have also extended to the Kurdish periphery where the PKK has been engaged in a fierce fight with the Turkish state since the mid-1980s. ${ }^{4}$ The decimation of many prominent pro-Kurdish associations, TV channels, news agencies and radio stations; the dismissal of over 11,000 schoolteachers deemed to be linked with the PKK (Kurdistan Workers' Party); the removal of over 90 mayors of the pro-Kurdish HDP (Peoples' Democratic Party) and its regional sister-party, the DBP (Democratic Regions Party); and the detention of over 10 HDP deputies on an array of charges related to alleged involvement in, and support for, terrorism are salient examples.

International human rights law seeks to protect the rights of minorities during states of emergency. Most notably, the ICCPR explicitly incorporates 'as one of the conditions for the justifiability of any derogation' in Article 4 that the derogation measures should not 'involve discrimination solely on the ground of race, color, sex, language, religion or social origin'. The ECHR, on the other hand, does not explicitly pronounce on the prohibition of discrimination in its derogation clause of Article 15, but it does contain two legal norms on

\footnotetext{
${ }^{1}$ See, Turkey, Derogation to the Convention on the Protection of Human Rights and Fundamental Freedoms Notification (ETS No.5), JJ8187C Tr./005-191 22 July 2016

${ }^{2}$ See, Turkey, Notification under Article 4(3) of International Covenant on Civil and Political Rights, C.N.580.2016.Treaties-iv.4, 2 August 2016.

${ }^{3}$ See, Turkey, Derogation to the Convention on the Protection of Human Rights and Fundamental Freedoms Notification (ETS No.5), JJ8719C Tr./005-223, 8 August 2018

${ }^{4}$ The PKK and Da'esh are the only 'other terrorist organizations' mentioned by name in the Turkish Government's Memorandum to the Venice Commission. See, Turkey, 'Memorandum prepared by the Ministry of Justice of Turkey for the visit of the delegation of the Venice Commission to Ankara on 3 and 4 November 2016 in connection with the emergency decree laws', CDL-REF(2016)067, 23 November 2016.
} 
non-discrimination. ${ }^{5}$ Article 14 ECHR provides that Convention rights shall be secured without discrimination on a number of grounds, including 'association with a national minority' (ECtHR, Thlimmenos v Greece [2000] para. 33). Protocol 12 to the ECHR provides a more general prohibition of discrimination.

Moreover, Article 27 ICCPR more directly protects the rights of minorities. As explained below, derogation from some elements of Article 27 is legally impermissible. The ECHR, on the other hand, contains no minority rights provision. Therefore, there is no direct way for members of minority groups to claim minority rights in the ECHR regime though the European Court of Human Rights (ECtHR) has held that member states are under an obligation to uphold "international standards in the field of the protection of human and minority rights" (ECtHR Denizci v Cyprus [2001] para. 410). Furthermore, reference must also be made to the overlapping yet normatively independent group right of selfdetermination of peoples, a norm of jus cogens (ILC, Fourth Report on Peremptory Norms of General International Law 2019) and erga omnes character (ICJ, Portugal v Australia [1995] and Advisory Opinion [2004]), which is enshrined, in international treaties (Article 1 of the ICCPR \& ICESCR) and forms part of modern customary international law (UNGA, Resolution 1514 (XV) [1960] and Resolution 2625 (XXV) [1970]).

Against that background, this chapter seeks to shed light on an unexplored aspect of the Turkish post-coup emergency regime. ${ }^{6}$ In particular, it seeks to map the impact of the Turkish derogation measures on Turkey's Kurds, and to test the derogation measures against the non-discrimination principle, minority rights, and the right of self-determination. Section I examines the scope of the Turkish post-coup emergency and the consequences thereof. It then zooms-in on the operation of the derogation measures vis-à-vis the Kurdish people by arguing that they cannot be understood merely as extraordinary actions taken against the specific threat arising from the failed coup (or so called, 'other terrorist attacks'); rather, they must be understood in a much wider sense encompassing the historical and ongoing persecution of the Kurdish minority.

The following two sections analyze the state of emergency through the lens of certain human rights. Section II focuses on the individual right of non-discrimination and minority rights. The section scrutinizes the principles of necessity, proportionality and nondiscrimination within the derogations regime. The section argues that notwithstanding the negative impact on the Kurds it seems unlikely that the human rights bodies will resort to a broad and encompassing use of the non-discrimination principle. It then considers the linked question of whether the minority rights contained in Article 27 of the ICCPR tell us anything about the legality of particular state of emergency measures. It will be argued that one can build a plausible case that certain measures taken during the state of emergency, and which Turkey might plausibly claim to be covered by its derogations, were in violation of Article 27 .

Section III takes the argument further by engaging with the crux of the Kurdish Question in Turkey, namely the group right of self-determination. In concrete terms, insofar as the derogation measures have arguably disproportionately targeted Turkey's Kurds and shrunk the political space for articulating Kurdish demands, it is important to establish

\footnotetext{
${ }^{5}$ Despite its lack of a minority rights provision, the ECHR is not completely blind to questions of minority group protection and does, to a limited extent, engage with them indirectly.

${ }^{6}$ There is an emerging literature on the Turkish state of emergency in the aftermath of the 15 July coup attempt and the post-coup emergency measures. The existing scholarship has so far focused on the legality of the collective dismissals of thousands of public servants from the perspective of ECHR law (see, Ruys and Turkut 2018); on the use of exceptional national security and emergency powers in the fight against terrorism in Turkey (see, Turkut 2019); on the question whether the Turkish failed coup could be regarded as an 'emergency that threatens the life of a nation' under Article 4 ICCPR and Article 15 ECHR (see, Nugraha 2018); on the legitimacy and proportionality of Turkey's post-coup derogation (See, Altiparmak and Gurol 2019); and on the perceptions of the victims of human rights violation during the postcoup crackdown (see, Aydin and Avincan 2020). Finally, for a comparative analysis in the context the recent declarations of state of emergencies by Ukraine, France, and Turkey, see Mariniello 2019.
} 
whether they can be reconciled with the right of self-determination of Turkey's Kurds by analyzing the normative guiding principles that might be derived from international law. The section argues that certain state of emergency measures run counter to the procedural and substantive aspects of that jus cogens right.

\subsection{The Post-Coup Emergency and the Kurdish People in Turkey}

\subsubsection{The Scope of the Post-Coup Emergency}

Before fully embarking on mapping the Turkish derogation measures with a particular focus on Turkey's Kurds, one must consider the scope of the state of emergency. As noted above, Turkey's derogation notices are broad in scope, and cover a wider range of threats than those posed by the groups, which were directly involved in the planning and implementation of the failed coup. By making a very general reference to the series of events that unfolded in Turkey on the night of 15 July 2016, and by mentioning 'other terrorist acts' with no further elaboration, the notices indicated Turkey's intention to "take required measures in the most speedy and effective manner" in its fight against all terrorist organizations.

The Turkish Government purported to justify this position in a notification letter of 25 July 2016 to the CoE, in which it asserted that FETÖ's "widespread infiltration" combined with "grave and violent attacks against national security" made it necessary (where it was not previously thought necessary) to derogate from certain human rights obligations. ${ }^{7}$ Later, in its Memorandum of 23 November 2016 to the Venice Commission, the Turkish authorities asserted that there are close links between FETÖ and the PKK, with the latter taking advantage of the state's perceived vulnerability.

Leaving aside the question of what sort of close relationship can be drawn between FETÖ and the PKK (and leaving aside the questionable assumption that any entity that might benefit from the actions of another is therefore closely linked with it) the most relevant question is whether the Turkish Government was "reasonably entitled to consider that normal legislation offered insufficient resources for the campaign against terrorism and that recourse to measures outside the scope of the ordinary law... was called for" (ECtHR, Ireland $v$ UK [1978] para.117). Put differently, could the public emergency in post-coup Turkey justify a lawful derogation from Turkey's international human rights obligations given that a derogation regime is normally intended to be a response to the circumstances of a specific emergency? And if so, could the emergency measures be justified if the focus shifts primarily towards 'other terrorist attacks' (Venice Commission 2016)? As aptly observed, "[a]lthough the notion of a public emergency might be defined in the abstract with relative ease, the application in concreto of such definition gives rise to numerous legal problems to which, so far, either only partial solutions have been found, or none at all" (Svenson-McCarthy 1998, 195).

The ECtHR, when it ruled on the validity and legitimacy of the Turkish derogation for the first time in the Mehmet Altan and Sahin Alpay cases of 20 March 2018 did not question this factual basis for the scope of the Turkish post-coup state of emergency. It relied on the finding by the Turkish Constitutional Court (TCC) in the Aydin Yavuz and Others (TCC, [2017]) case that "the fact that the attempted coup had taken place at a time when Turkey had been under violent attack from numerous terrorist organizations had made the country even more vulnerable". By simply highlighting that "...the attempted military coup disclosed the existence of a 'public emergency threatening the life of the nation' within the meaning of the Convention", thus justifying Turkey's recourse to the derogation clause under Article 15

\footnotetext{
${ }^{7}$ See, Turkey, Derogation to the Convention on the Protection of Human Rights and Fundamental Freedoms Notification (ETS No.5), JJ8190C Tr./005-192, 25 July 2016
} 
ECHR (seemingly) in connection with the 15 July attempted coup, the ECtHR failed to take into account the dangers allegedly posed by these 'other terrorist organizations' and refrained from making a determination on the Turkish recourse to measures outside the scope of the its ordinary law in its broader fight against terrorism (ECtHR Altan v Turkey [2018] para.92 and Alpay v Turkey [2018] para.76). In other words, the ECtHR too uncritically rode on the coat tails of the TCC.

This amplified the deference effect seen in the context of national security at a domestic level by giving it an international dimension. To date, the human rights bodies have conceded the government's assertion of a state of emergency although in principle there must be a close nexus between the circumstances of the public emergency and the proportionality of measures taken in response thereto (UNHRC, General Comment No. 29 (2001) para.4) On the ECHR level, with only one exception, the European organs have consistently deferred to national authorities' assessment of whether or not a 'public emergency threatening the life of the nation' exists. ${ }^{8}$ The ECtHR has even acquiesced to the UK Government's assertion that the threat of terrorism prior to any actual attack was a public emergency threatening the life of the nation (ECtHR, $A \&$ Others $v$ United Kingdom [2009]). As regards the ICCPR regime, the United Nations Human Rights Committee (UN HRC or Committee) has traditionally been reluctant to determine the existence of a state of emergency and, in one instance, based its finding on "the assumption that there exists a situation of emergency" while generally acknowledging "the sovereign right of a State to declare a state of emergency is not questioned" (UNHRC, Landinelli Silva v Uruguay [1981]). As early as 1978, reacting to this clear disconnect between principles under international human rights treaties and the deferential practice of treaty bodies, one commentator observed how "a critical on-looker would be justified in concluding that the chances of a state being found guilty of wrongly declaring an emergency are somewhat remote" (Green 1979, 548).

\subsubsection{Mapping the Impact of the Turkish State of Emergency on the Kurdish People}

After the failed coup, Turkey adopted a wide range of emergency decrees, which granted "very far-reaching, almost unlimited discretionary powers for administrative authorities" (CoE Commissioner for Human Rights 2016) and targeted anyone deemed a terrorist to counter the severe dangers to public security and order from terrorist activities, whether or not the latter are related to the coup attempt. Unsurprisingly, the Kurdish movement has borne the brunt of the emergency, suffering a crackdown marked by higher levels of political imprisonment and greater restrictions on freedom of assembly and association and on electoral aspects of self-determination (UN OHCHR 2017, 22).

The re-securitization of the Kurdish question, whereby Turkey seeks to turn every move towards Kurdish rights into an existential threat, makes the situation even more threatening from a Kurdish perspective (Bezwan 2018, 62). This situation is not unique in Turkish history: from the beginning of the Republic in 1923, Turkey adopted repressive measures towards Kurdish culture and language, and established a military presence in the Kurdish region, leading to the announcement of martial law and state of emergency in the Turkish southeast (McDowall 2004) This is particularly due to the fact that Turkey has clung to the idea of a Turkish identity as the origin of national unity with one language and one nation (See Article 3 of the Turkish Constitution) and sought to impose a common set of traditions and historical-cultural narratives on all segments of society and, in case of resistance, eliminate other identities and ethnic minorities through a policy of denial and suppression (Yeğen 1999 and Oeter 2018, 212). Due to this mind-set, the 'Kurdish problem'

\footnotetext{
${ }^{8}$ The exception concerns the European Commission on Human Rights' rejection of the claim by the Greek "Colonel's regime" that a state of emergency existed that justified its having taken certain measures following the 1967 military coup that had brought it to power.
} 
has been reduced to a security issue and the important cultural and other socio-political elements of the Kurdish Question have been sidelined (Barkey and Fuller 1998). Rather than addressing the cause of the security issue by engaging with the Kurds' very real and legitimate grievances (a strategy that was, eventually, adopted by the UK in regards to Northern Ireland with much success), Turkey has opted to focus intently on the violent effects of those unaddressed grievances.

The collapse of the peace process in 2015 led to this re-securitization narrative. It is argued that a resolution of the Kurdish issue proved beyond reach of a peace process marked with "divergent understandings and irreconcilable expectations and the lack of a concrete roadmap" (International Crisis Group 2015). Since July 2015, the Turkish Government has adopted a policy reminiscent of the violence of the 1990s, which is marked by a campaign of counter-insurgency, the declaration of open-ended curfews and 'temporary security zones", and anti-terrorism operations that killed and displaced a large number of civilians ${ }^{10}$ and caused destruction in the Kurdish majority region. Echoing these human rights concerns, in early 2016, the United Nations Committee on the Elimination of Racial Discrimination stressed that in the context of the fight against terrorism, the enforcement of anti-terrorism legislation and security-oriented policies have resulted in racial profiling of members of the Kurdish community (UNCERD Report 2016). Such legislation has been applied to curtail the right to freedom of expression and association and led to the unwarranted arrest, detention and prosecution of thousands of Kurds.

This trend against the Kurdish minority reached a new peak via far-reaching powers under the state of emergency. Amid a growing onslaught against Kurdish opposition voices during the state of emergency period, on 1 September 2016, the Turkish Ministry of Education suspended 11,500 schoolteachers deemed to be linked with the PKK and revoked their licenses to teach, over 90 percent of whom were serving in Kurdish-speaking municipalities. ${ }^{11}$ Turkey, however, provided little evidence, thus giving rise to concerns that they were dismissed as a precautionary measure based on mere suspicion (UN OHCHR 2017).

On the same day, Turkey adopted Decree No. 674 that allowed for the removal and replacement of locally elected officials with trustees appointed by the Turkish Ministry of Interior where a mayor, deputy mayor or member of municipal council has been dismissed or arrested due to the offences of aiding and abetting terrorism and terrorist organizations. An overwhelming number of those replaced had links with the Kurdish movement (DBP Local Authorities Commission Report 2017). Despite the official termination of the Turkish postcoup state of emergency, this practice has continued in the Kurdish regions. The majority of replaced co-mayors have been jailed on politically motivated terrorism charges after their removal from elected office (HDP Report 2019).

Throughout the emergency period, Turkey permanently closed at least 20 Kurdish media outlets for 'spreading terrorist propaganda' (Amnesty International 2017). It also took

\footnotetext{
${ }^{9}$ In June 2007, the Turkish Armed Forces announced via their website that 'temporary security zones' would be formed in three Kurdish provinces: Şırnak, Siirt and Hakkari. Since then, many additional areas have been declared as provisional security zones. The Law on Prohibited Military Zones and Security Zones No. 2565 provided the legal basis of 'temporary security zones'. The Law No. 2565 was adopted on 18 December 1981 by the 12 September military regime and it still remains in effect. When the PKK announced to end the ceasefire in July 2015, a total of 37 areas had become 'temporary security zones' in Turkey's east and southeast. The declaration of such zones enables the military to effectively occupy the area and exercise powers similar to those, which existed under the state of emergency regimes. It has been argued, however, that since then a de facto state of emergency has continued to exist in a legally dubious form and substance in the context of 'temporary security zones'. Thus, despite a de jure revocation in 2002, a de facto exceptional regime has continued to raise the spectre of past emergency rule in Turkey's southeast. See also K. Yildiz and S. Breau 2010, 22 and KHRP $2008,14$.

10 "According to official figures related to Sur, for example, 22000 persons were displaced for 50 terrorists rendered ineffective; a ratio of 440." See, Memorandum on the Human Rights Implications of Anti-Terrorism Operations in South-Eastern Turkey, Council of Europe Commissioner for Human Rights, Comm.DH (2016) 39, 2 December 2016, para. 28.

${ }^{11}$ Many lower level public servants, such as schoolteachers, not mentioned in the appended lists of Decrees, have been dismissed by decisions of the relevant administrative entities and judicial bodies. As envisaged in Article 4(1) of Decree no.667, these dismissals take place "upon the proposal of the commission to be established by the minister in the relevant ministries and with the approval of the Minister."
} 
steps to erode the institutional base of the Kurdish movement and severely restricted their right to organize via political parties. Thousands of HDP and DBP party officials, including its two-chairs, have been detained on anti-terror grounds (Human Rights Watch 2017). More than 10 HDP deputies have been stripped of their seats in parliament on the same grounds (EU Progress Report 2019).

\subsection{Testing Turkey's Post-Coup Measures Against the Non-Discrimination Principle and Minority Rights}

\subsubsection{Non-Discrimination}

The post-coup derogation measures significantly targeting the Kurdish minority prima facie raise an issue of non-discrimination. For example, in relation to the mass dismissals of the Kurdish school teachers, the OHCHR noted its concerns that this practice poses the question of the political or racial profiling of members of an ethnic group and thus of Turkey's compliance with the prohibition of discrimination (UN OHCHR 2017). Relatedly, the Kurdish representatives alleged that this measure was introduced as a form of collective punishment based on their ethnic origin and language (UN OHCHR 2017).

However, these measures do not necessarily violate the principle of nondiscrimination. According to the consistent case law of international human rights bodies, a difference in treatment on the basis of criteria such as race, ethnicity or national origin may be considered lawful if it pursues a legitimate aim (in the ECtHR jargon) or in other words, has reasonable and objective justification (in the UN HRC jargon) and if there is reasonable relationship of proportionality between the means employed and the aim sought to be realized.

The argument here is that it is unlikely that the human rights bodies will resort to an imaginative use of the non-discrimination principle with regard to the Turkish derogation measures affecting the Kurdish minority. There are at least three reasons for this - one contextual, the others technical. The contextual argument is that, as is clear from Turkey's derogation notice, at least on paper the post-coup state of emergency was declared to counter the threats arising from the failed coup and other terrorist attacks, rather than being targeted against a particular minority group (Kurdish minority) or a religious group (Gülen movement). More specifically, various reasons or justifications were given by the Turkish government for the use of policies of detention/dismissals towards Kurdish people in light of their alleged affiliation with the out-lawed PKK. It is also worth noting that after the declaration of the state of emergency in July 2016, several other terrorist attacks were committed in Turkey, attributed to the PKK, which may justify certain measures with exceptional character taken as part of the Turkey's effort to protect itself against such attacks (Venice Commission 2016).

The Turkish state may therefore be able to meet the legitimate aim requirement by referring to its national security interests. This test has however been criticized as being a mere rhetorical assertion and redundant (Partsch 1993 and Arnardóttir 2003). Perhaps more can be made of the second leg of the justification test: proportionality between means and ends. As such, the assessment will mainly hinge upon the proportionality test, which "requires that the distinction on which a given measure is based is assessed for its suitability and effectiveness in relation to the aim pursued and for its effects on individuals and groups" (Moeckli 2008, 94).

This takes us to our technical arguments. These interrelated arguments stem from the fact that emergency situations put the non-discrimination principles in a reverse spotlight minimizing their potential role in such situations. The first argument is that the proportionality tests contained in all derogation clauses are almost identical to the proportionality test under the non-discrimination principle (Oraa 2004). This is to say that any derogating measure 
would have to be strictly required by the exigencies of the situation-a test unlikely to be met by a derogating measure that involves discrimination. To put it the other way round, the impermissible restrictions on the right to non-discrimination (either because not supported by objective or reasonable justification or not proportionate to the threat) are also not lawful for the operation of the derogation clause. Following this line of thought, it is clear that derogation measures that are carried out discriminatorily are very unlikely to be 'strictly required'. Based on this, human rights bodies tend to examine such discrimination claims in times of emergency primarily from the perspective of the proportionality test under the derogation clause. For example, in the context of the ECHR, this is patently evidenced in the $A \&$ Others $v$. UK case when the ECtHR was required to consider the application of the British Anti-Terrorism, Crime and Security Act (ATCS Act 2001), which permitted an extended power for the UK Government to arrest and detain the non-British -foreign national- terrorist suspects in the context of public emergency said to flow from the terrorist attacks of 11 September 2001 (ECtHR, A \& Others $v$ United Kingdom [2009]). Notwithstanding its considerable deference and the low threshold as regards what is encompassed by the notion of 'public emergency threatening the life of the nation', the European Court found that 'the derogating measures were disproportionate in that they discriminated unjustifiably between nationals and non-nationals' (ECtHR, $A \&$ Others $v$ United Kingdom [2009] para.191). Here, the Strasbourg Court simply saw no need to consider the complaints concerning Article 14 ECHR separately because the measures were found to be disproportionate to the threat and to be discriminatory in their effect.

The second technical argument is closely related to the first: the question of proportionality is closely linked to the doctrine of margin of appreciation. The tendency of human rights bodies towards a wide margin of appreciation during emergency situations complicates the issue further. Although the ECHR, for example, in its general holdings on Article 14 ECHR, stated that where a differential treatment that goes beyond the reasonable permissible limitations is based on race or ethnic origin, 'the notion of objective and reasonable justification must be interpreted as strictly as possible', ${ }^{12}$ it has frequently conceded a certain margin of appreciation for the states 'in assessing whether and to what extent differences in otherwise similar situations justify a different treatment' (Arai-Takahashi 2002, 23). Although the UN HRC does not expressly refer to the margin of appreciation, its supervisory practice reveals a similar approach to the ECtHR (Henrard 2011). In any case, derogation from human rights treaties produces an unclear aporia in international jurisprudence where it contains the most extreme statements of the margin of appreciation.

Cases arising from the fifteen years of emergency governance in the Kurdish dominated southeast of Turkey between 1987 and 2002 are particularly illustrative. In its judgment in Aksoy v. Turkey, the ECtHR acknowledged that "...the particular extent and impact of PKK terrorist activity in South-East Turkey has undoubtedly created, in the region concerned, a public emergency threatening the life of the nation" ([1996] para.70), yet the most grave human rights violations were recorded as the Turkish state pursued oppressive policies against the Kurdish people (Reidy et al. 1997). This approach escalated to a point where Turkish officials engaged in torture, disappearances, extra-judicial killings, and forced displacement of civilians (Kurban and Gülalp 2013). Most cases concerned alleged discrimination in relation to Kurdish identity; the contentions of the applicants, however, were found to be unsubstantiated (Akdivar and Others v Turkey [1998] and Menteş and Others $v$ Turkey [1998]) or manifestly ill founded (Doğan v Turkey [2004]) and thus, not proved to be

\footnotetext{
${ }^{12}$ See i.a. Orsus and others $v$ Coratia ([2010] para. 149) in which the European Court held that "very weighty reasons would have to be put forward before the Court could regard a difference of treatment based exclusively on the ground of ethnic origin as compatible with the Convention".
} 
based on race or ethnic origin. ${ }^{13}$ In a number of cases, moreover, the Court simply declined to review altogether (Sadak and Others $v$ Turkey [2001]). In this respect, it is argued that the wide margin of appreciation is hardly conducive to a proper 'objective and reasonable justification' scrutiny' (Arnardóttir 2003, 171). This leads to the conclusion that, as for the protection of minorities, there seems to be little role for the non-discrimination principle (Harris et al. 2009).

\subsubsection{Minority Rights}

In its notification under Article 4(3), Turkey derogated from its obligations under Article 27 of the ICCPR, which provides for the rights of ethnic, religious and linguistic minorities "to enjoy their culture, to profess or practice their own religion, or to use their own language" in community with others. The right applies to individuals differentiated by their membership of a minority community. The most widely accepted definition of a minority community for the purpose of Article 27 refers to the group's non-dominance, numerical inferiority, nationality of the state concerned, differing ethnic, religious, or linguistic characteristics, and to their sense of solidarity directed towards preserving their identities (Capotorti 1979). The existence vel non of a minority falls to be determined objectively, whether or not a state party decides to recognize a particular group as such (UNHRC, General Comment No. 23 (2001) para.4). Whatever the indeterminacies inherent in the definition of a minority, there is no reasonable doubt that Turkey's Kurds fall within its ambit.

The substantive protections derived from or integral to Article 27 are multifaceted. At its most basic level, the right requires protection of the physical existence of the minority community (Thornberry 1980). This is reflected in Article 1 of the UN Declaration on the Rights of Persons Belonging to National or Ethnic, Religious and Linguistic Minorities, which obligates states to protect the "existence" of their minorities (UNGA Res. 47/135). It also requires the application of generally applicable non-discrimination and equality rights to members of minority communities (UNGA Res. 47/135 Article 4/1). Together, these basic elements of minority rights protection may be described as "essential starting points" to facilitate Article 27 (Pentassuglia 2002). But the right in Article 27 is much more substantial than a commitment to formal, legal equality and physical existence because it is concerned with the maintenance and development of minority identities. In short, minority rights are about ensuring that members of minority groups are not assimilated against their will (UN Economic and Social Council 2005, para.27). One might describe it as "a legal prohibition on acts of cultural genocide" (Wheatley 2005, 35), but one should also be cognizant of the fact that unwanted assimilation can be achieved without the necessary intent (so crucial a part of the definition of genocide) to do so. Indeed, the canon of legal instruments pertaining to minority rights seeks, to some extent, to tackle 'hidden' or structural causes of assimilation.

In order to fulfill the rights under Article 27, states are under an obligation to take positive measures aimed at creating favorable conditions to enable members of minority communities to maintain and develop their cultures, languages, religions, traditions and customs (UNGA Res. 47/135 Article 4/2). This includes, for example, an obligation to provide opportunities for minorities to learn their mother tongue or (more importantly) to learn via the medium of their mother tongue (UN Economic and Social Council 2005, para.27). Article 27 is therefore concerned with enabling members of minority groups to do something that members of the majority take for granted-namely, to maintain and develop their identities. In that sense, the right is concerned with equality in a substantive rather than a

\footnotetext{
${ }^{13}$ It is of great significance to note that in many cases before the ECtHR where the Kurds alleged discrimination, they mostly based those claims on grounds of ethnic origin, rather than of being member of a national minority. See, Kurban and Gulalp $2013,170$.
} 
merely formal sense insofar as it ensures that members of minority groups are not legally viewed as abstract human beings, completely divorced from their cultural backgrounds.

Despite the importance of Article 27, Article 4(2) of the ICCPR does not include it among the list of non-derogable rights, and its normative status is open to doubt. The Badinter Arbitration Committee (Opinion Nos. 1-2, 1992) opined that minority rights have jus cogens status, but scholars have cast doubt on that opinion (Craven 1996) and the most recent report of the International Law Commission's Special Rapporteur on Peremptory Norms of International Law in 2019 makes no mention of it. To make matters even more complicated, Turkey's reservation to Article 27 purports to limit its scope to particular non-Muslim communities, excluding the Kurdish minority (Bayır 2013). This raises some important questions. First, given Turkey's reservation to Article 27, what could the provision possibly have to say about the country's subsequent measures affecting Kurds' minority rights, such as the closure of privately operated schools teaching the Kurdish language (IHD Report 2016), the removal of bilingual Turkish-Kurdish street signs (Ahval News 2018), the shuttering of Kurdish language media outlets (Amnesty International 2017), and the solitary confinement of prisoners who use the Kurdish language during family visits (Tevgera Jinên Azad 2017)? Secondly and relatedly, was Turkey's derogation from Article 27 legally valid?

To begin with Turkey's reservation, it must first of all be noted that the UN HRC in 1987 accepted a reservation that purported to exclude Article 27 in toto (UNHRC, H.K. $v$ France [1987] paras. 8.5-8.6). But the Committee's acceptance in that case was not based on any substantive reasoning beyond noting that the reservation was "unequivocal". More recent scholarship has engaged with the International Law Commission's 2011 Guide to Practice on Reservations to Treaties, which significantly advances international lawyers' understanding of the law of treaty reservations, and argues that there are plausible grounds for deeming Turkey's reservation invalid (Phillips 2019). It is not necessary to repeat that argument here; suffice it to say that if the argument is correct then Turkey's reservation is no obstacle to Article 27 providing legal grounds for challenging Turkey's severe backsliding in the field of Kurdish minority rights. Turning to Turkey's attempt to derogate from Article 27, in its General Comment No. 29 the UN HRC notes that where certain rights are not listed in Article $4(2)$ of the ICCPR there are nevertheless "elements" of those rights that "cannot be made subject to lawful derogation under article 4" (UN HRC, General Comment No. 29 (2001) para.13). Article 27 is one such right, and the Committee is of the view that the elements of the right that are bound-up with the prohibition against genocide, the notion of nondiscrimination in Article 4(1), and freedom of religion "must be respected in all circumstances" (UN HRC, General Comment No. 29 (2001) para.13/c). This can be read in a number of ways. First, it might mean that derogations from Article 27 are prima facie invalid. This is the stance adopted by the International Commission of Jurists $(2018,10)$. But this interpretation of the Committee's comments does not sit easily with the fact that Article 27 is not included in the list of non-derogable rights in Article 4(2). Instead, it is submitted that the Committee's comments clarify that it is precisely the most foundational elements of Article 27 that must be respected in all circumstances. Discrimination against members of minority communities (in the formal, limited sense), physical genocide of minorities, and abridgement of their freedom of religion are never lawful no matter how grave the threat to the life of the nation. Whether desirable or not, states may - in our view-lawfully derogate from the other aspects of Article 27.

Nevertheless, the other elements of Article 27 cannot be subject to derogation at will. As the Committee notes, there is a "legal obligation to narrow down all derogations to those strictly required by the exigencies of the situation" (UNHRC, General Comment No. 29 (2001) para.6). Derogation measures must be strictly necessary to deal with the threat and proportionate to its nature or extent. And when one considers Turkey's restrictions on Kurdish cultural institutions and its destruction of cultural objects, it is difficult to see how much of it 
was either necessary to deal with the threats giving rise to the state of emergency or how it was proportionate to that aim. For instance, it requires a vivid imagination to envisage a scenario in which bilingual street signs or private schools teaching children the Kurdish language constitute even a partial threat - almost certainly not one that requires their total abolition. Furthermore, the almost complete closure of Kurdish media outlets was criticized by Minority Rights Group International (2016) in terms of Turkey's legal obligation to take positive measures in support of minorities and the UN's Special Rapporteur on the right to freedom of opinion and expression (2016) noted his particular concern about the "decimation" of Kurdish media despite attempts to justify it in terms of stability. Additionally, the UN $\mathrm{OHCHR}$ notes that the authorities were using machinery to raze objects of Kurdish cultural heritage to the ground after security operations against the PKK and its affiliates had taken place and after the local population had been forced to flee (UN OHCHR 2017, para.33). Prima facie this has all the appearances of a violation of Article 27 which was either unnecessary or, at the very least, disproportionate.

In short, during the state of emergency, Turkey's limited but significant progress in terms of Kurdish minority rights was rolled back, and this is open to legal criticism on Article 27 grounds notwithstanding Turkey's reservation and notwithstanding Turkey's derogation from the provision. There are, therefore, plausible grounds for concluding that certain measures taken during the state of emergency, which impacted upon the Article 27, right were not necessary or proportionate in the sense mentioned above.

\subsection{The Crux of the Question: The Kurdish Struggle for Self-Determination}

The right of self-determination, expressed in common Article 1 of the ICCPR and the ICESCR, may be characterized as both an erga omnes and jus cogens norm, which is to say that it is a norm owed to the international community as a whole and from which no derogation is permitted. For purposes of analytical clarity, this chapter differentiates between individual minority rights on the one hand, and the group right of self-determination on the other. The former right belongs to individual members of minority groups whereas the latter right belongs to "peoples" understood either as a corporate entity or a collection of individuals (Jones 2013).

In practice, however, there is a significant degree of overlap between the two norms. A group right to autonomy, for example, is a form of self-determination that might be desirable, or even necessary, for the maintenance and development of minority cultures and languages (OSCE 1999). Outside of the colonial context, the modern right of selfdetermination is only, at best, concerned with external self-determination (independent statehood) as an ultima ratio in exceptional cases of very severe human rights abuses and unrepresentative government (Raic 2002). But it is also widely recognized that selfdetermination has an internal aspect. ${ }^{14}$ In short, internal self-determination is about the relationship between the state and the various communities (including minority communities) that together make up the whole "people" of the territory (Kingsbury 2000). It is less about automatic rights to particular outcomes for particular groups (secession, statehood, autonomy, and so on $^{15}$ ) and more about finding ways of maximizing political, social, economic and cultural participation within the framework of the state and in the context of the particularity of each claim.

It is also widely recognized that the right of self-determination contains remedial elements (Canadian Supreme Court, Reference re Secession of Quebec [1998] para.124),

\footnotetext{
${ }^{14}$ The Canadian Supreme Court notes that internal self-determination, understood as "a people's pursuit of its political, economic, social and cultural development within the framework of an existing state", is the usual way in which the right of self-determination is fulfilled. See, Reference re Secession of Quebec [1998] 2 R.C.S., para. 126.

${ }^{15}$ Recent scholarship argues convincingly that there is no direct right to autonomy under international law, see Nam and Fessha $2018,530$.
} 
which are aimed at mitigating the pathologies arising from international law's allocation of sovereignty around the globe and its failure to allocate it to arguably deserving groups (Macklem 2015). In practice, the right of self-determination therefore has the capacity to legitimize the disaggregation of state sovereignty to (for example) autonomous regions and to tie these constitutional rearrangements to a "normative universe" (Bell 2008) of international law, particularly when such rearrangements serve to offset the negative effects of state sovereignty on minority groups. As well as performing these legitimizing and remedial functions, the right of self-determination requires inclusive processes of negotiation when a minority group clearly expresses a desire to pursue constitutional change, such as the introduction of a territorial autonomy arrangement (Klabbers 2006).

In sum, the right of self-determination is ontologically grounded in the state system and seeks to "reconstitute the political normality of statehood" (Koskenniemi 1994). But it can validate important reorientations of relationships between minorities and the state (such as the introduction of a territorial autonomy arrangement), and it requires states to negotiate with representatives of minority communities in good faith. The right can therefore be used by oppressed minority groups to obtain normative support for their legitimate demands and to criticize governments that fail to take those demands seriously.

In terms of Kurdish self-determination, "pro-Kurdish" political parties have quite consistently called for some kind of territorial autonomy arrangement (Günes 2009). To take a recent example, a former co-chair of the pro-Kurdish HDP has referred to the quasi-federal Spanish model of territorial autonomy as an example of the form of government that the HDP recommends (Demirtas 2015). There is, in fact, a more radical project called Democratic Confederalism, which forms a core part of the Kurdish self-determination claim (Jongerden 2017). In brief, this revolutionary project focuses on bottom-up grassroots democracy against the nation-state form, and on the empowerment of women (Öcalan 2013). But at least in the short to medium term, as a matter of revolutionary tactics, it appears to be compatible with something like the Spanish model.

The claim to territorial autonomy along broadly Spanish lines is clearly a far-reaching one. It goes beyond calls for non-discrimination and individual minority rights and demands a "thicker" measure of executive and legislative power. It is a call for a "right to be different" and to be given some space "to preserve, protect, and promote values which are beyond the legitimate reach of the rest of society" (Hannum 1990, 4). Given the self-determination framework outlined above, one can construct a strong normative argument that this particular claim in the particular historical and contemporary circumstances of Turkey garners strong normative support from the right of self-determination. The argument is that the construction of the Turkish state, followed by the ongoing attempt to forge a monolithic Turkish nation harnessed to the Turkish ethnie, has given rise to a range of negative pathologies. For the Kurds, this has involved severe cultural, political, economic, and social marginalization. Their language is being slowly killed (Hassanpour 2012), their political parties are excluded and hobbled (Watts 2010), and their local economy has been deliberately underdeveloped (Yadirgi 2017). Moreover the war with the PKK, brought on by the oppression of the Kurds, has claimed tens of thousands of mostly Kurdish lives (International Crisis Group 2011). All told, the Kurdish situation in Turkey is one in which "the legal and political ideal of territorial unity causes moral havoc and social, economic, and cultural injustice resulting in great suffering and endless strife for these entrapped peoples" (Falk 2000, 102). These pathologies - which are bound-up with international law's allocation of sovereignty and the way in which it legitimizes its use-need to be mitigated, and self-determination in the form of territorial autonomy is one ingredient in an overall solution. ${ }^{16}$

\footnotetext{
${ }^{16}$ Given the fact that roughly half of Turkey's Kurds do not live in the southeast, territorial autonomy arguably has to be complemented with some form of cultural autonomy.
} 
To return to the focus of this chapter, certain measures taken by Turkey during its state of emergency may be criticized on self-determination grounds. On a procedural level, the lifting of parliamentary immunity via Law No. 6718 led to a number of prosecutions against HDP members of parliament and exposed others to "the risk of excessive sanctions for speech related to their activity as Members of Parliament" (Venice Commission 2016, para.54). The political nature of some of these actions has been confirmed by the ECtHR. For example, the Court ruled that a former co-chair of the HDP was held in extended pre-trial detention for "the predominant ulterior purpose of stifling pluralism and limiting freedom of political debate" (Demirtas $v$. Turkey [2018] para.273). According to a third party intervention in that case, this was part of a broader crackdown on opposition voices that was "wholly unjustified under international law" (Article 19 \& Human Rights Watch 2017, para.33). The CoE's Commissioner for Human Rights (2017, para.61) noted that the crackdown on legitimate representatives of the Kurdish people "disenfranchised millions of voters" and "reduced the scope of democratic debate". In terms of the right of self-determination, the post-coup-attempt crackdown on the HDP has made it significantly more difficult to advance legitimate Kurdish claims. As a mechanism for Kurdish political participation, representation at the national level is both an important aspect of internal self-determination in its own right and an important part of the process towards negotiating "thicker" forms of self-determination, such as autonomy. Alongside the earlier decision to end peace talks, this demonstrates that legitimate Kurdish claims are not being taken seriously. Thus, as well as being legally questionable on a variety of individual rights grounds (freedom of expression, the right to political participation, freedom of association) the attempt to hobble the HDP runs counter to the normative requirements contained in the right of self-determination.

As well as hobbling the HDP, Turkey also seriously undermined local Kurdish-run institutions. Turkey's heavily circumscribed power of local government (a limited form of administrative autonomy) has been used by pro-Kurdish parties to "try to establish an alternative Kurdish governmental presence and to construct a new Kurdish subject or collective community" (Watts 2010, 142). Important projects have been pursued in the cultural, political and economic realms in an effort to build towards demands for more substantial autonomy. However, in September 2016 Decree No. 674 altered the Law on Municipalities and paved the way for democratically elected municipal organs to be seized by government appointed trustees. More than 90 elected mayors affiliated with the Kurdish movement were removed (under the usual terrorism pretext) and replaced with government appointed trustees. This "suspension of local democracy" - as Human Rights Watch describes it - continued after the official end of the state of emergency with the removal of three elected Kurdish mayors in Diyarbakir, Van and Mardin (Human Rights Watch 2019).

Decree No. 674 was criticized by, inter alia, the Venice Commission (Opinion No. 888/2017) on certain individual rights grounds and on the basis of the European Charter for Local Self-Government. The criticism focused, among other things, on the fact that the replacement of elected officials with trustees was not necessary or strictly required by the exigencies of the situation. But the measures also ran counter to the normative requirements contained in the right of self-determination. Indeed, the limited administrative autonomy granted under Turkish law is likely (with improvements and augmentations) to be part of an overall solution to the Kurdish Question. In the Spanish model, for example, the state consists of democratic municipalities and provinces as well as self-governing communities (Spanish Constitution, Section 137). In fact, given the significant obstacles to achieving far-reaching territorial autonomy in Turkey any time soon (Kymlicka 2004), strengthened local governments (combined, perhaps, with some form of cultural autonomy) might be a more achievable short term palliative. Throwing this into reverse - as Turkey has done-fails to take into account the normative requirements of the right of self-determination. 


\subsection{Conclusion}

In this chapter we have mapped the impact of Turkey's widening state of emergency on the Kurdish minority and tested its derogation measures against the non-discrimination principle, minority rights, and the right of self-determination. Our overall conclusion is that certain measures taken during the state of emergency were unlawful or may be criticized on the grounds of minority rights and the right of self-determination.

Although the widening scope of Turkey's state of emergency (which goes far beyond threats directly linked to the coup attempt) is certainly questionable, the generally conservative international institutions responsible for interpreting and implementing human rights have afforded an exceptionally wide margin of appreciation to states when it comes to the legal requirements for triggering a state of emergency and determining its scope. Furthermore, although Turkey's Kurds have been forced to shoulder an intolerable burden during the state of emergency, it seems likely that any prima facie discriminatory treatment will not be classified as such due to the wide margin of appreciation afforded to states.

Whether or not Turkey's emergency measures are legally discriminatory, they can still be criticized on human rights grounds. Article 27 of the ICCPR applies to Turkey notwithstanding its reservation thereto and its derogation therefrom. Certain measures taken to erode Kurds' right to maintain and develop their own language and culture - such as the almost complete abolition of Kurdish-language media, the closure of private schools teaching the Kurdish language, and the removal of bilingual signs-were either unnecessary or disproportionate to meet the threat of terrorism.

The right of self-determination, contained in common Article 1 of the ICCPR and ICESCR, is usually fulfilled internally. It is about reorienting the relationships between minorities and the state in order to maximize political, cultural, social and economic participation. It also contains remedial elements that are supposed to mitigate the adverse consequences arising from how international law allocates sovereignty around the globe and legitimizes its use. The right also contains a procedural element, which requires states to take minority claims for constitutional reforms seriously. Within that framework, Turkey's Kurds can obtain strong normative support for some kind of autonomy, such as the disaggregation of sovereignty to autonomous regions. But by taking measures to hobble the pro-Kurdish HDP, Turkey has both undermined a key mechanism for Kurdish political participation at the national level and narrowed the available space for articulating legitimate Kurdish claims. Turkey has therefore signaled its ongoing refusal to take Kurdish demands seriously. Furthermore, by removing elected co-mayors and municipal officials and replacing them with centrally appointed trustees, Turkey has undermined a key pillar of the 'thicker' form of selfdetermination sought by the Kurds. Indeed, given the obstacles to securing a fully-fledged territorial autonomy regime any time soon, strengthened local governments represent a paving stone on the path to a meaningful and lasting self-determination arrangement to better manage (if not answer) the Kurdish Question.

\subsection{References}

Ahval News, 'Kurdish language signs removed from Diyarbakir streets', April 2018

Altiparmak Kerem and Gürol Senem. 2019. Turkey's Derogation of Human Rights under the State of Emergency: Examining its Legitimacy and Proportionality. Austrian Review of International and European Law Online 22(1): 101-136.

Amnesty International, 'Journalism is Not a Crime: Crackdown on media freedom in Turkey', May 2017

Arai-Takahashi Yutaka. 2002. The Margin of Appreciation Doctrine and the Principle of Proportionality in the Jurisprudence of the ECHR. Intersentia. 
Arnardóttir Oddný Mjöll. 2003. Equality and non-discrimination under the European Convention on Human Rights. Martinus Nijhoff Publishers, 2003.

Aydin Hasan and Avincan Koksal. 2020. Intellectual crimes and serious violation of human rights in Turkey: a narrative inquiry. The International Journal of Human Rights, 1-29.

Bakircioglu Onder and Dickson Brice. 2017. The European Convention in conflicted societies: the experience of Northern Ireland and Turkey. International \& Comparative Law Quarterly, 66(2): 263-294.

Barkey Henri and Fuller Graham. 1998. Turkey's Kurdish Question. Lanham:Maryland.

Bayır Derya. 2013. Turkey, the Kurds and the legal contours of the right to selfdetermination. Kurdish Studies 1(1): 5-27.

Bell Christine. 2002. On the Law of Peace. Oxford University Press.

Bezwan Naif. 2018. Addressing the Kurdish Self-Determination Conflict: Democratic Autonomy and Authoritarianism in Turkey. In Democratic Representation in Plurinational States, eds. Ephraim Nimni and Elçin Aktoprak, 59-82. Palgrave Macmillan.

Capotorti Francesco. 1979. Study on the Rights of Persons Belonging to Ethnic, Religious and Linguistic Minorities, UN Doc. E/CN.4/Sub.2/384/Rev.1.

Codaccioni Vanessa. 2018. The State of Emergency in France: community profiling and the discriminatory exception regime. Monitor Racism.

$\mathrm{CoE}$, Memorandum on the human rights implications of the measures taken under the state of emergency in Turkey, Council of Europe Commissioner for Human Rights, Comm.DH (2016) 35, 7 October 2016

Craven Miles. 1996. The European Community Arbitration Commission on Yugoslavia. British Yearbook of International Law 66: 333-413

Demirtas Selahattin. 2015. The Middle East, the Kurdish Peace Process in Turkey, and Radical Democracy. Turkish Policy Quarterly 13: 27-33.

European Commission, 'EU Turkey Progress Report 2019' \{COM(2019) 260 final\}, 29 May 2019

Falk Richard. 2000. Human Rights Horizons: The Pursuit of Justice in a Globalizing World. Routledge.

Green Leslie. 1979. Derogation of Human Rights in Emergency Situations. Canadian Yearbook of International Law/Annuaire canadien de droit international 16: 92-115.

Güneş Cengiz. 2009. Unpacking the 'Democratic Confederalism and Democratic Autonomy': Proposals of Turkey's Kurdish Movement. In Autonomy as a Model for Minority SelfGovernment: From Theory to European and Middle Eastern Perpective, eds. O. Akbulut \& E. Aktoprak, 246-267. Brill.

Hannum Hurst. 1990. Autonomy, Sovereignty, and Self-Determination. University of Pennsylvania Press.

Harris David, O'Boyle Michael and Warbrick. 2009. Law of the European Convention on Human Rights, Oxford University Press.

Hassanpour Amir, J. Sheyholislami and T. Skutnabb-Kangas. 2012. Kurdish: Linguicide, resistance and hope', International Journal of the Sociology of Language 217: 1-18.

Henrard Kristin. 2011. Boosting Positive Action: The Asymmetrical Approach towards Non Discrimination and Special Minority Rights. Heidelberg Journal of International Law 71:379-418.

Human Rights Association (IHD), 'Report on Recent Situation in the Kurdish Region of Turkey', November 2016

Human Rights Watch, 'France: Abuses Under State of Emergency' 3 February 2016

Human Rights Watch, 'Turkey: Crackdown on Kurdish Opposition', 20 March 2017

Human Rights Watch, Turkey: 3 Kurdish Mayors Removed from Office', 20 August 2019

Human Rights Watch, Turkey: Normalising the State of Emergency, 20 July 2018 
International Commission of Jurists, 'Justice Suspended: Access to Justice and the State of Emergency in Turkey', 2018

International Crisis Group, A Sisyphean Task? Resuming Turkey-PKK Peace Talks, 17 December 2015

International Crisis Group, Ending the PKK Insurgency, September 2011

Jones Peter. 2013. Groups and human rights. In Human Rights: The Hard Questions, eds. C. Holder \& D. Reidy, 100-114. Cambridge University Press.

Jongerden Joost. 2017. The Kurdistan Workers' Party (PKK): Radical Democracy and the Right to Self-Determination Beyond the Nation-State. In The Kurdish Question Revisited, eds. G. Stansfield \& M. Shareef, 245-258. Hurst.

Klabbers Jan. 2006. The Right to be Taken Seriously: Self-Determination in International Law. Human Rights Quarterly 28:186-206.

Koskenniemi Martti. 1994. National Self-Determination Today: Problems of Legal Theory and Practice. The International and Comparative Law Quarterly 43:241-269.

Kurban Dilek and Gülalp Haldun. 2013. A complicated affair: Turkey's Kurds and the European Court of Human Rights. In The European Court of Human Rights: Implementing Strasbourg's Judgments on Domestic Policy, eds. Dia Anagnostou, 166187. (Edinburg University Press.

Kymlicka Will. 2004. Renner and the accommodation of sub-state nationalisms. In National Cultural Autonomy and its Contemporary Critics, ed. Eprahim Nimni, 137-149. Routledge.

Macklem Patrick. 2015. The Sovereignty of Human Rights. Oxford University Press.

Mariniello Triestino. 2019. Prolonged emergency and derogation of human rights: Why the European Court should raise its immunity system. German Law Journal 20(1): 46-71.

McDowall David. 2004. A Modern History of Kurds. London: IB Tauris.

Moeckli Daniel. 2008. Human Rights and Non-discrimination in the 'War on Terror'. Oxford University Press

Nam Nora Ho Tu and Fessha Yonathan. 2018. Revisiting the Place and Use of Territorial Autonomy under International Law. International Journal on Minority and Group Rights 25(4): 530-560.

Nugraha Yordan. 2018. Human rights derogation during coup situations. The International Journal of Human Rights 22(2): 194-206.

Öcalan Abdullah. 2013. Liberating Life: Woman's Revolution. International Initiative Edition.

Oeter Stefan. 2018. The Kurds between discrimination, autonomy and self-determination. In Autonomy and Self-Determination: Between Legal Assertions and Utopian Aspirations, ed. Peter Hilpold, 208-246. Edward Elgar.

OSCE, Office for Democratic Institutions and Human Rights, Expert Meeting Report, 27-28 October 2018

OSCE, The Lund Recommendations on the Effective Participation of National Minorities in Public Life \& Explanatory Note, September 1999

Pentassuglia Gaetano. 2002. Minorities in International Law: an introductory study. Council of Europe Publishing.

Phillips Thomas. 2019. The (In-) Validity of Turkey's Reservation to Article 27 of the International Covenant on Civil and Political Rights. International Journal on Minority and Group Rights 1: 1-28.

Raic David. 2002. Statehood and the Law of Self-Determination. Brill.

Reidy Aisling, Francoise Hampson, and Kevin Boyle. 1997. Gross violations of human rights: Invoking the European Convention on Human Rights in the case of Turkey. Netherlands Quarterly of Human Rights 15 (2):161-173. 
Ruys Tom and Turkut Emre. 2018. Turkey's post-coup 'purification process': collective dismissals of public servants under the European Convention on Human Rights. Human Rights Law Review 18(3): 539-565.

Svensson-McCarthy Anna. 1998. The International Law of Human Rights and States of Exception: With Special Reference to the Travaux Preparatoires and the Case-law of the International Monitoring Organs. Martinus Nijhoff Publishers, p.19

Tevgera Jinên Azad, 'Information Report on the State of Emergency and Violations of Women's Rights in Prisons', November 2017.

Thornberry Patrick. 1980. Is There a Phoenix in the Ashes? - International Law and Minority Rights. Texas International Law Journal 15:421-444.

Turkut Emre. 2019. Accommodating Security Imperatives v. Protecting Fundamental Rights: The Challenge of States of Emergency in the Context of Countering Terrorism in Turkey. Security and Human Rights 28 (1-4): 62-91.

UN Committee on the Elimination of Racial Discrimination, Concluding observations on the combined fourth to sixth periodic reports of Turkey, 11 January 2016.

UN Office of the United Nations High Commissioner for Human Rights, Report on the human rights situation in South-East Turkey July 2015 to December 2016, February 2017

Venice Commission, Opinion on the Provisions of the Emergency Decree Law No. 674 of 1 September 2016, Opinion No. 888/2017.

Venice Commission, Opinion on the suspension of the second paragraph of article 83 of the constitution (parliamentary inviolability), October 2016, CDL-AD(2016)027

Watts Nicole. 2010. Activists in Office: Kurdish Politics and Protest in Turkey. University of Washington Press.

Wheatley Steven. 2005. Democracy, Minorities and International Law. Cambridge University Press.

Yadirgi Veli. 2017. The Political Economy of the Kurds of Turkey: From the Ottoman Empire to the Turkish Republic. Cambridge University Press.

Yeğen Mesut. 1999. The Kurdish question in Turkish State Discourse. Journal of Contemporary History 34(4): 555-568.

Y1ldiz Kerim and Breau Susan. 2010. The Kurdish conflict: international humanitarian law and post-conflict mechanisms. Routledge.

\subsection{Notes on Contributors}

Emre Turkut is a doctoral researcher at Ghent University and a member of the Ghent Rolin-Jaequemyns International Law Institute (GRILI). He previously held a Swedish Institute fellowship at Uppsala University. Emre's research covers a variety of fields within the domain of public international law and international human rights law, including derogation from human rights, state of emergency, human rights in the fight against terrorism, self-determination and remedial secession doctrine. He is a DAAD visiting fellow at the Hertie School's Centre for Fundamental Rights (2019/2020).

Thomas Phillips is a senior lecturer in law at Liverpool John Moores University. His research focuses on public international law, human rights law, Kurdish studies, and critical approaches to international law. His $\mathrm{PhD}$-which he completed at the University of Liverpool-concerned the right of self-determination as it applies to the Kurds in Turkey, with a particular focus on mother tongue education and political participation. Thomas has also been involved in activities related to his research, including trial and election observation missions in Turkey at the invitation of the HDP. 